\title{
Development of Novel Dinuclear [Gd(III)D03VA] Complexes Decorated with Iso- valeric acid as MRI Contrast Agents for Tumor Diagnosis
}

\author{
T. Lurthu Pushparaj, V.Alexander \\ ${ }^{* 1}$ Department of Chemistry, Einstein College of Engineering, Tirunelveli-627012. \\ 2Department of Chemistry, Loyola College, Chennai-600034. \\ Email: *chemlurthu2006@gmail.com
}

\begin{abstract}
.
The synthesis and relaxivity of a new gadolinium(III) complex of a Cyclen macrocycle having 2-bromoisovaleric acid pendant arm (DO3VA) and its Dinuclear complex is reported. The longitudinal relaxivity $\left(r_{1 p}\right)$ of $\left[\mathrm{Gd}_{2}\left\{\mathrm{pr}(\mathrm{DO} 3 \mathrm{VA})_{2}\right\}\left(\mathrm{H}_{2} \mathrm{O}\right)_{4}\right]$ is $11.32 \mathrm{mM}^{-1}$ $\mathrm{s}^{-1}$ which correspond to a "per Gd" relaxivity of $5.66 \mathrm{mM}^{-1} \mathrm{~s}^{-1}$. The "per Gd" $r_{1 \mathrm{p}}$ values are higher than that of the clinically approved CAs. The transverse relaxivity of the complex is $12.10 \mathrm{mM}^{-1} \mathrm{~s}^{-1}$ which correspond to a "per Gd" relaxivity of 6.50 . The "per $G d " r_{2 p}$ value of the complex is higher than that of the parent complex $\left[\mathrm{Gd}(\mathrm{DO} \mathrm{BVA})\left(\mathrm{H}_{2} \mathrm{O}\right)_{2}\right]$. The $r_{2 \mathrm{p}} / r_{1 p}$ value of 1.07 for the complex indicates that the complex is $T_{1}$-weighted CA. The complex exhibits $\mathrm{pH}$-dependent $r_{1 \mathrm{p}}$ and $r_{2 \mathrm{p}}$ values at pH 2.6-10.6 indicating their potential use as $\mathrm{pH}$-responsive contrast agent for MRI. The complex exhibit higher $r_{1 p}$ values of $30.51 \mathrm{mM}^{-1} \mathrm{~s}^{-1}$ in the presence of HSA indicating the formation of macromolecular adduct with HSA.
\end{abstract}

Key words: MRA Contrast agents, Blood Pool Agents, MRI, pH-responsive, DO3VA, HSA-Binding.

\section{INTRODUCTION}

Development of cancer-specific contrast enhancing agents for providing "hot" spot magnetic resonance images would improve the sensitivity of MRI for tumor detection. ${ }^{\text {TThe }}$ ability to noninvasively detect a small number of cells at the onset of metastatic growth presents a major challenge not only to clinicians but also to the experimental community. Cancer detection through the in vivo noninvasive visualization of cellular and biochemical events has been gaining rapid momentum in the burgeoning field of molecular imaging. ${ }^{2}$ Due to high spatial resolution, ${ }^{3} \mathrm{MRI}$ has become the clinical imaging procedure for a large number of studies involving the central nervous system, especially the brain, ${ }^{4}$ visualizing soft tissues, ${ }^{5}$ diagnosis of various diseases and the examination of almost all organs, ${ }^{6}$ and imaging of physiological properties such as diffusion, perfusion, and vascularity of tissues. ${ }^{3,7} \mathrm{MRI}$ also provides real-time images of visualizing drug delivery, ${ }^{8}$ monitoring biological processes, and following functional changes in vivo. $8 \mathrm{a}, 9$ The image contrast obtained in MRI is a threedimensional signal intensity map of the spatially encoded proton signal of the in vivo water molecules in a given volume element (voxel). ${ }^{10}$ Contrast in MRI images arises from variations in the relaxation times among water protons caused by differences in the local environment in tissues. For many clinical applications, it is a common practice to administer an exogenous chemical, called contrast enhancing agent, to improve the image contrast. ${ }^{10 \mathrm{~b}}$ Currently, about $30 \%$ of the MRI examinations use contrast agents. 5,11

Contrast agents can be divided into two classes depending on whether they cause changes in longitudinal relaxation time $\left(T_{1}\right)$ or transverse relaxation time $\left(T_{2}\right)$ of the water protons, known as positive and negative agents, respectively. ${ }^{12}$ The relaxivity reflect the efficiency of a contrast agent to accelerate longitudinal and transverse water proton relaxation rates $1 / T_{1}$ and $1 / T_{2}$, respectively, normalized to one millimole concentration of the agent. ${ }^{10 a, 13}$ The signal observed in MRI tends to increase with an increase in $1 / T_{1}$ and decrease with an increase in $1 / T_{2}$ and it is usual for contrast agents to affect both $1 / T_{1}$ and $1 / T_{2}$ to varying degrees. ${ }^{10 a}$ Positive contrast agents are commonly made up of paramagnetic materials, mainly those based on metal ions with large number of unpaired electrons such as $\mathrm{Mn}(\mathrm{II})$ and $\mathrm{Gd}(\mathrm{III})$. Positive contrast agents increase the brightness of images while the negative contrast agents give dark images. Superparamagnetic materials such as iron oxide nanoparticles are employed as negative CAs. ${ }^{1}$ 
Low molecular weight complexes of paramagnetic metal ions are administered as contrast agents prior to the acquisition of MRI images. ${ }^{1}$ Over the last decade there has been an increasing interest in the chemistry of $\mathrm{Gd}$ (III) complexes because they have been used in diagnostic medicine as contrast agents for MRI. The symmetric S-state of $\mathrm{Gd}(\mathrm{III})$ is a more hospitable environment for electron spins leading to a much slower electronic relaxation rate. Due to the large magnetic moment $\left(\mu_{\text {eff }}{ }^{2}=g^{2}(S(S+1))=63\right)$ with a long electron spin relaxation time $\left(10^{-9} s\right) \mathrm{Gd}(\mathrm{III})$ is widely used as a contrast agent for MRI. ${ }^{14}$ Free gadolinium ions get accumulated as phosphate salts in lysomes of heptocytes and macrophages in spleen, bone marrow, and lungs and as a result of its high in vivo toxicity $\mathrm{Gd}(\mathrm{III})$ ion is complexed with ligands to form stable complexes. ${ }^{15}$ The commercially used contrast agents are $\mathrm{Gd}(\mathrm{III})$ complexes of polyaminocarboxylate ligands.

The choice of a contrast enhancing agent suitable for clinical use is governed by stringent biological requirements such as (i) high solubility in water (of the order of $0.5 \mathrm{M}$ ), (ii) effective catalyst for relaxation of protons in the bulk water, i.e., a high water proton relaxivity, (iii) better body distribution, (iv) low in vivo toxicity, i.e., extremely inert to the loss of the metal ion, (v) selective tissue/organ localization, (vi) rapid tissue clearance, and (vii) high thermodynamic stability and kinetic inertness. A sizable increase in relaxivity is achieved if $\mathrm{Gd}(\mathrm{III})$ chelates are covalently or noncovalently linked to macromolecules, because the rotational correlation time becomes comparable to or longer than the electronic and water-exchange correlation times. ${ }^{16}$ The conjugation of gadolinium(III)chelates to polymers, dendrimers, or biological molecules increases the rotational correlation time and improves the relaxivity "per Gd" atom. Targeting polynuclear conjugates are envisioned to provide MRI with the ability to image the low-concentration receptors by delivering a large payload of $\mathrm{Gd}(\mathrm{III})$ chelates. The present investigation could also be extended to the development of macromolecular CAs by appending the $\mathrm{Gd}(\mathrm{DO} 3 \mathrm{VA})$ chelate onto the macromolecular substrates such as polymers, ${ }^{17}$ proteins, and dendrimers. ${ }^{18}$

The mononuclear $\mathrm{Gd}(\mathrm{III})$ complexes of 2-isovaleric acid functionalized cyclen derivatives and polynuclear $\mathrm{Gd}(\mathrm{DO} 3 \mathrm{VA})$ complexes covalently conjugated to different amide linkers and core molecules can be subjected to detailed kinetic and pharmacokinetic studies to evaluate their suitability as contrast agents. Additional relaxivity gains may be achieved by increasing the number of the mobile protons of the amide linkers by the prototropic mechanism. The incorporation of 2-isovaleric acid groups is expected to increase the molecular weight as well as molecular dimension of the complex resulting in a longer rotational correlation time and thus leading to high proton relaxivity. The relaxivity of the mononuclear and polynuclear $\mathrm{Gd}(\mathrm{III})$ chelates of DO3VA depends on the residence time of the inner-sphere water molecules and the steric crowding and the formation of a secondary hydration sphere by the bulky 2-isovaleric acid group. Thus, there is a wide scope of studying the rotational dynamics and other relaxivity parameters for these systems. The gains made in the relaxivity of this monoand polynuclear gadolinium complexes would shed more light on the design parameters for future MRI contrast agents.

After the first generation clinically approved extracellular contrast agents, the next largest class of applications may involve blood pool agents that serve as contrast agents for MRI angiography. Magnetic resonance angiography represents a more attractive procedure for patients and doctors for vascular imaging. The addition of lipophilic groups to the carbon backbone of polyazapoly carboxylates profoundly alters the pharma cokinetic and biodistribution properties of their gadolinium complexes. Furthermore, the interaction of the Gd(DO3VA) complexes with human serum albumin (HSA), their stability at the physiological $\mathrm{pH}$, and their vascular retention time can be studied to evaluate their suitability as contrast agents for magnetic resonance angiography (MRA).

\section{EXPERIMENTAL SECTION}

\section{A. Materials.}

Benzenesulfonyl chloride, TRIS base, Celite ${ }^{\circledR}$,

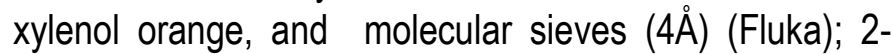
bromoisovaleric acid and gadolinium(III) chloride (Aldrich); cyclen (Strem chemicals); and sodium bromide, potassium hydroxide, sodium hydroxide, disodium hydrogen phosphate, magnesium turnings, iodine, and sodium carbonate (anhydrous) (Merck, India) were used 
as such. Charcoal (Merck, India) was used for the purification of compounds after activating by heating at $150{ }^{\circ} \mathrm{C}$ overnight. Calcium chloride (anhydrous) and sodium wire (Merck, India) were used for drying purposes. Hydrochloric acid (AR, 35.4\%, $d=1.18$, Merck India) was used as supplied. Silica gel (blue indicator, Fluka) was used as desiccant after activating by heating in an oven at $200{ }^{\circ} \mathrm{C}$ overnight. Amberlite IR-120 $\left(\mathrm{H}^{+}\right.$ form, 16-45 mesh), Amberlite IR-400 (Cl- form, 20-50 mesh), Dowex 50W x 8-200 $\left(\mathrm{H}^{+}\right.$-form, $8 \%$ cross linking, 100-200 mesh), and Dowex $1 \times 8-400$ (Cl- form, $8 \%$ cross linking, 200-400 mesh) (Aldrich) were washed with double distilled water five times before use. $\mathrm{KBr}$ (FT-IR grade), DMSO- $d_{6}(99.9$ atom $\% D)$, acetone- $d_{6}(99.9$ atom $\% D$ ), $\mathrm{D}_{2} \mathrm{O}(100$ atom \% D) (Aldrich), and mineral oil (for IR spectroscopy, Fluka) were used as received. Super dry ethanol, super dry methanol, and triply distilled water were prepared by the standard procedures. ${ }^{15}$ HPLC grade water (Merck, India) was used to prepare solutions of the complexes for relaxivity measurements.

Preparation of buffer solutions. Glycine-HCl buffer for $\mathrm{pH} 2.6$ and 3.6, ${ }^{16}$ glycine-NaOH buffer for $\mathrm{pH} 9.6$ and 10.6, ${ }^{17}$ sodium acetate buffer for $\mathrm{pH} 4.6$ and $5.6,{ }^{17,18} \mathrm{TRIS}-\mathrm{HCl}$ buffer for $\mathrm{pH} 7.2,7.5,8.0$, and 8.5 were prepared by the literature methods.

Preparation of $4.5 \%$ (W/V) human serum albumin (HSA) solution and complex/HSA samples. HSA was dissolved in PBS buffer (10 mM sodium phosphate and $150 \mathrm{mM}$ sodium chloride, $\mathrm{pH}$ 7.4). An HSA molecular weight of $680,00 \mathrm{Da}$ (Fluka) was used to convert \% (w/v) to a molar concentration.

Binding of complexes to HSA. Gd complex/HSA samples ranging from $0.20 \mathrm{mM}$ to $2.50 \mathrm{mM} \mathrm{GdL}$ and $0.066 \mathrm{mM}(0.45 \%)$ to $0.66 \mathrm{mM}(4.5 \%)$ HSA were prepared in PBS buffer. Each complex/HSA sample was incubated at $37^{\circ} \mathrm{C}$ for $1 \mathrm{~h}$ before $T_{1}$ and $T_{2}$ measurements.

\section{B. Methods}

Physical Measurements. Infrared spectra were recorded on a Perkin-Elmer Spectrum RX-I FT-IR Spectrometer in the range of $4000-400 \mathrm{~cm}^{-1}$. Spectra for the solid samples were recorded by making transparent $\mathrm{KBr}$ pellets. The electrospray ionization mass spectra were recorded on a micromass Quattro II triple quadrupole mass spectrometer. The sample dissolved in methanol, acetonitrile, or water was introduced into the ESI source through a syringe pump at the rate of $5 \mu \mathrm{L}$ per min. The ESI capillary was set at $3.5 \mathrm{kV}$ and the cone voltage at $40 \mathrm{~V}$. The average spectra of 6-8 scans were printed. $\mathrm{CHN}$ microanalyses were carried out using a Perkin-Elmer 2400 Series II CHNS/O Elemental Analyzer interfaced with a Perkin-Elmer AD 6 Autobalance. Helium was used as the carrier gas. Caution! All hygroscopic compounds were dried in desiccator over silica gel for 24 $\mathrm{h}$ prior to the analysis. ${ }^{1} \mathrm{H}$ and ${ }^{13} \mathrm{C}$ NMR spectra were recorded on a Bruker AVANCE III $500 \mathrm{MHz}$ multinuclei NMR spectrometer. Broad band gradient probe head 'BBO' $5 \mathrm{~mm}$ probe was used for the ${ }^{1} \mathrm{H}$ NMR measurements. Inverse Quad Probe head $5 \mathrm{~mm}$ 'QXI' was used for the ${ }^{13} \mathrm{C}$ NMR measurements. $400 \mathrm{MHz}{ }^{1} \mathrm{H}$ NMR spectra were recorded on a Jeol GSX-400 multinuclear NMR spectrometer working at $25^{\circ} \mathrm{C}$. The $100 \mathrm{MHz}{ }^{13} \mathrm{C}$ NMR spectra were recorded using Jeol GSX-400 instrument. The standard $5 \mathrm{~mm}$ probe was used for the ${ }^{1} \mathrm{H}$ and ${ }^{13} \mathrm{C}$ NMR measurements. $\mathrm{pH}$ measurements were made using Labindia $\mathrm{PICO}^{+} \mathrm{pH} /$ Conductive meter $(3 \mathrm{P})$ calibrated with buffer solutions of pH 4.0, 7.0, and 9.2.

Longitudinal relaxivity measurements. The longitudinal relaxivity of the $\mathrm{Gd}(\mathrm{III})$ complexes were determined from the spin lattice relaxation time $\left(T_{1}\right)$. The $T_{1}$ measurements were carried out on a Bruker minispec $m q 20$ NMR Analyzer operating at a frequency of $20 \mathrm{MHz}$ and the temperature was maintained using a temperature console at $37 \pm 0.1{ }^{\circ} \mathrm{C}$. The solutions of the complexes were taken in a $180 \times 10 \mathrm{~mm}$ stoppered glass tube. The instrument parameters were optimized for each $T_{1}$ measurement. Solutions of six concentrations $(0.2,0.5$, 1.0, 1.5, 2.0, and $2.5 \mathrm{mM}$ ) for each complex were prepared in HPLC grade water (Merck, India) in $5 \mathrm{~mL}$ standard measuring flask (Vensil, Class "A"). The presence of free gadolinium(III) ion in the solution has been checked by xylenol orange test. The $T_{1}$ measurements were made using the standard inversion recovery pulse sequence $\left(180^{\circ}-T-90^{\circ}\right)$ with phase sensitive detection with $\tau$ values ranging from $50 \mu \mathrm{s}$ to $6 \mathrm{~s}$ for each concentration of the complex. ${ }^{19}$ The computer program "Excel" (version 2007) was used to plot the time versus signal intensity to get a monoexponential plot and $T_{1}$ was calculated from the plot. The $T_{1}$ values for six concentrations of each complex were measured. The $T_{1}$ curves for all the concentrations have a monoexponential 
decay character. The longitudinal relaxivity was calculated from the slope of the regression line, obtained by the plot of the concentration of the complex versus $1 / T_{1}$ by least squares fitting method. The instrument was calibrated by measuring the relaxivity of $\left[\mathrm{Gd}(\mathrm{DO} 3 \mathrm{~A})\left(\mathrm{H}_{2} \mathrm{O}\right)_{2}\right]$ in aqueous solution $\left(r_{1 \mathrm{p}}=4.63 \mathrm{mM}^{-1} \mathrm{~s}\right.$ 1, $20 \mathrm{MHz}$ and $37^{\circ} \mathrm{C}$; lit.20 $4.80 \mathrm{mM}^{-1} \mathrm{~s}^{-1}, 20 \mathrm{MHz}, 40^{\circ} \mathrm{C}$ ).

Transverse relaxivity measurements. The transverse relaxation time $\left(T_{2}\right)$ was determined by the standard CarrPurcell-Meiboom-Gill (CPMG) pulse sequence $\left(90^{\circ}-\mathrm{T}-180^{\circ}\right)$ with a $\tau$ value of $50 \mu \mathrm{s} .{ }^{21}$ The computer program "Excel" (version 2007) was used to plot the time versus signal intensity to get an exponential curve and $T_{2}$ was calculated from the graph. The $T_{2}$ values for six concentrations were measured for each complex. The transverse relaxivity was calculated from the slope of the regression line, obtained by the plot of the concentration of the complex versus $1 / T_{2}$ by least squares fitting method. All other experimental conditions are the same as that employed for the $T_{1}$ measurements.

\section{Synthesis of Ligand and Complex}

$\{1,4,7,10-T e t r a a z a c y c l o d o d e c a n e-4,7,10$-tris-2-isovaleric acid\} DO3VA (1). A solution of 2-bromoisovaleric acid $(6.31 \mathrm{~g}, 34.86 \mathrm{mmol})$ in $50 \mathrm{~mL}$ water was slowly added to a solution of cyclen $(2 \mathrm{~g}, 11.62 \mathrm{mmol})$ and sodium hydroxide $(1.39 \mathrm{~g}, 34.86 \mathrm{mmol})$ in $150 \mathrm{~mL}$ water in a double surface round bottom flask, connected to a cryogenic water circulator bath and placed over a magnetic stirrer. The $\mathrm{pH}$ of the solution was maintained at 10 by adding $1 \mathrm{~N}$ aqueous sodium hydroxide solution for $12 \mathrm{~h}$. It was cooled to room temperature, filtered, and dried in vacuum. The desired tri $\mathrm{N}$-alkylated product DO3VA 25 was separated from the tetra $\mathrm{N}$-alkylated product by ion exchange column chromatography (Amberlite, $\mathrm{H}^{+}$form) by eluting with water. Colorless crystalline solid, yield $(3.96 \mathrm{~g}) 72 \%, \mathrm{mp} 160{ }^{\circ} \mathrm{C}$. Anal. Calcd. for $\mathrm{C}_{23} \mathrm{H}_{44} \mathrm{~N}_{4} \mathrm{O}_{6}\left(M_{\mathrm{r}}=473\right)$ : C, 58.45; $\mathrm{H}, 9.38 ; \mathrm{N}$, 11.85. Found: C, 58.43; H, 9.36; $\mathrm{N}, 11.81$. ESI MS: $\mathrm{m} / \mathrm{z}$ $473[\mathrm{M}]^{+}, 411\left[\mathrm{M}-\mathrm{CH}_{2} \mathrm{O}_{3}\right]^{+}$(loss of one hydroxyl and one carboxyl group), $379\left[(\mathrm{M}-4)-\mathrm{C}_{2} \mathrm{H}_{4} \mathrm{O}_{4}\right]^{+}$(loss of two carboxyl groups), $275\left[(\mathrm{M}+4)-\mathrm{C}_{10} \mathrm{H}_{18} \mathrm{O}_{4}\right]^{+}$(loss of two isovaleric acid groups). ${ }^{1} \mathrm{H}$ NMR $\left(\mathrm{D}_{2} \mathrm{O}, 278 \mathrm{~K}\right): \delta 1.29\left(9 \mathrm{H}, \mathrm{d},{ }^{a} \mathrm{CH}_{3}\right), 1.40$ $\left(9 \mathrm{H}, \mathrm{d},{ }^{b} \mathrm{CH}_{3}\right), 2.50\left(3 \mathrm{H}, \mathrm{m}, \mathrm{CH}_{3}{ }^{-} \mathrm{CH}-\mathrm{CH}_{3}\right), 3.48(16 \mathrm{H}, \mathrm{t}$, $\left.{ }^{d} \mathrm{CH}_{2}\right), 4.41\left(3 \mathrm{H}, \mathrm{d},{ }^{e} \mathrm{CH}\right) .{ }^{13} \mathrm{C}$ NMR $\left(\mathrm{D}_{2} \mathrm{O}, 278 \mathrm{~K}\right): \delta 15.8$ $\left({ }^{a} \mathrm{CH}_{3}\right), 18.7\left({ }^{b} \mathrm{CH}_{3}\right), 28.1\left({ }^{c} \mathrm{CH}\right), 31.5\left({ }^{d} \mathrm{CH}_{2}\right), 49.5\left({ }^{e} \mathrm{CH}_{2}\right)$, $52.6\left({ }^{\mathrm{f}} \mathrm{CH}_{2}\right), 77.3\left({ }^{\circ} \mathrm{CH}_{2}\right), 181.1(\mathrm{COOH})$.

\section{1,3-Bis[1-(4,7,10-tris-2-isovalericacid-1,4,7,10} tetraaza cyclododecanyl)]propane [pr(DO3VA $\left.)_{2}, 2\right]$. A solution of 1,3-dibromopropane $(0.16 \mathrm{~mL}, 0.82 \mathrm{mmol})$ in 50 $\mathrm{mL}$ of water was added dropwise to a suspension of 1,4,7,10-tetraazacyclododecane-4,7,10-tris-2-isovaleric acid (1) $(0.82 \mathrm{~g}, 1.72 \mathrm{mmol})$ and sodium carbonate $(0.05 \mathrm{~g}$, $0.43 \mathrm{mmol}$ ) in $100 \mathrm{~mL}$ of water at $60^{\circ} \mathrm{C}$ over a period of 1 $\mathrm{h}$. The reaction mixture was refluxed under stirring in argon atmosphere for $24 \mathrm{~h}$, cooled to room temperature, filtered, flash evaporated, and dried in vacuum. The resulting white solid was recrystallized in water: yield $(0.69 \mathrm{~g}, 88 \%), \mathrm{mp}$ $181^{\circ} \mathrm{C}$. Anal. calcd. for $\mathrm{C}_{49} \mathrm{H}_{92} \mathrm{~N}_{8} \mathrm{O}_{12}\left(M_{\mathrm{r}}=985\right)$ : C, 59.73; H, 9.41; N, 11.37. Found: C, 59.76; H, 9.36; N, 11.35. IR $\left(\mathrm{KBr}, \mathrm{cm}^{-1}\right): 3394 \mathrm{v}(\mathrm{O}-\mathrm{H}), 2960 \mathrm{v}(\mathrm{C}-\mathrm{H}), 2823 \mathrm{v}(\mathrm{C}-\mathrm{H}), 1642$ $v(\mathrm{C}=\mathrm{O}), 1068 \mathrm{v}(\mathrm{C}-\mathrm{N}), 748 \rho\left(\mathrm{CH}_{3}\right)$. MS (ESI): m/z 985 [M] ${ }^{+}$, $\left.966[(\mathrm{M}-4)-\mathrm{OH}]^{+}, 854\left[(\mathrm{M}+2)-\mathrm{C}_{3} \mathrm{H}_{3} \mathrm{O}_{6}\right)\right]^{+}$.

$\left[G d_{2}\left\{p r(D O 3 V A)_{2}\right\}\left(H_{2} \mathrm{O}\right)_{4}\right]$ (3). A solution of the ligand 2 (4.92 $\mathrm{g}, 5 \mathrm{mmol})$ in $40 \mathrm{~mL}$ of water was added to a solution of $\mathrm{GdCl}_{3} .6 \mathrm{H}_{2} \mathrm{O}(3.72 \mathrm{~g}, 10 \mathrm{mmol})$ in $50 \mathrm{~mL}$ of water. The $\mathrm{pH}$ of the reaction mixture was maintained at 7 throughout the reaction by adding an aqueous solution of $\mathrm{NaOH}$ and heated to $60^{\circ} \mathrm{C}$ under argon atmosphere for about $12 \mathrm{~h}$. It was cooled to room temperature, filtered through a $0.2 \mu \mathrm{m}$ filter funnel, flash evaporated, and dried in vacuum. The resulting colorless hygroscopic solid was purified by column chromatography (Dowex ion exchange resin, cationic) by eluting with water and recrystallized in water: yield $(5.05 \mathrm{~g}, 74 \%)$. Anal. calcd. for $\mathrm{C}_{49} \mathrm{H}_{94} \mathrm{~N}_{8} \mathrm{O}_{16} \mathrm{Gd}_{2}\left(\mathrm{Mr}_{\mathrm{r}}=\right.$ 1366): C, 43.39; $H, 7.02$; N, 8.02. Found: C, 43.36; $H$, 6.99; N, 8.01. IR (KBr, cm-1): $3462 \quad \mathrm{v}(\mathrm{O}-\mathrm{H})$ (acid), 2969 $v(\mathrm{C}-\mathrm{H}), 1616 \mathrm{v}(\mathrm{C}=\mathrm{O})$ (acid), $1022 \mathrm{v}(\mathrm{C}-\mathrm{N}), 769 \rho\left(\mathrm{CH}_{3}\right)$, $652 \rho(\mathrm{O}-\mathrm{H}), 539 \omega(\mathrm{O}-\mathrm{H}), 499 \mathrm{v}(\mathrm{Gd}-\mathrm{O})$. MS (ESI): $\mathrm{m} / \mathrm{z}$ $1365[\mathrm{M}-1]^{+}, \quad 1301 \quad\left[(\mathrm{M}-3)-\mathrm{CH}_{2} \mathrm{O}_{3}\right]^{+}, \quad 1175 \quad[(\mathrm{M}+2)-$ $\left.\mathrm{GdH}_{4} \mathrm{O}_{2}\right]^{+}$.

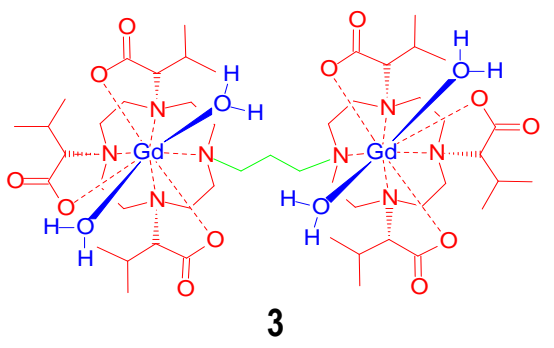

Fig.1. Struture of Ligand and Complex 


\section{Relaxivity Studies}

Longitudinal relaxivity of $\left[G d_{2}\left\{p r(D O 3 V A)_{2}\right\}\left(\mathrm{H}_{2} \mathrm{O}\right)_{4}\right]$. It exhibits a relaxivity of $11.32 \mathrm{mM}^{-1} \mathrm{~s}^{-1}$ which corresponds to 5.66 "per Gd". The "per Gd" $r_{1 p}$ value is $2.7,2.4$, and 3.0 units higher than that of $\left[\mathrm{Gd}(\mathrm{DOTA})\left(\mathrm{H}_{2} \mathrm{O}\right)\right]^{-}\left(r_{1 \mathrm{p}}=4.2 \mathrm{mM}^{-1} \mathrm{~s}^{-}\right.$ 1, $20 \mathrm{MHz}),\left[\mathrm{Gd}(\mathrm{DO} A \mathrm{~A})\left(\mathrm{H}_{2} \mathrm{O}\right)_{2}\right]\left(r_{1 \mathrm{p}}=4.8 \mathrm{mM}^{-1} \mathrm{~s}^{-1}, 20 \mathrm{MHz}, q\right.$ $=2)$, and $\left[\mathrm{Gd}(\mathrm{DTPA})\left(\mathrm{H}_{2} \mathrm{O}\right)\right]^{2-}\left(r_{1 \mathrm{p}}=3.8 \mathrm{mM}^{-1} \mathrm{~s}^{-1}, 20 \mathrm{MHz}, 25\right.$ ${ }^{\circ} \mathrm{C}$ ), respectively. The coordination sphere of each $\mathrm{Gd}$ metal ion in $\left[\mathrm{Gd}_{2}\left\{\mathrm{pr}(\mathrm{DO} 3 \mathrm{VA})_{2}\right\}\left(\mathrm{H}_{2} \mathrm{O}\right)_{4}\right]$ is similar to that of $\left[\mathrm{Gd}(\mathrm{DO} 3 \mathrm{~A})\left(\mathrm{H}_{2} \mathrm{O}\right)\right]$. The higher $r_{1 \mathrm{p}}$ value is due to the presence of four inner-sphere water molecules coordinated to the two $\mathrm{Gd}(\mathrm{III})$ ions, higher molecular weight, and limited internal flexibility.

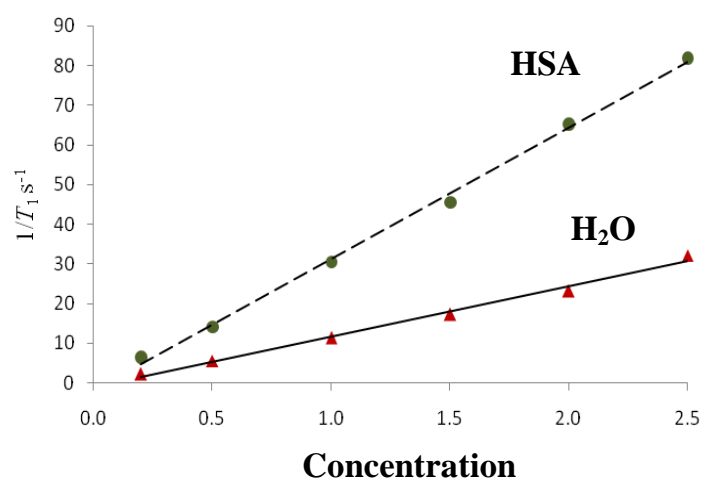

Fig.2. Longitudinal relaxivity of the complex in water and HSA.

Transverse relaxivity. The transverse relaxivity of $\left[\mathrm{Gd}_{2}\left\{\mathrm{pr}(\mathrm{DO} 3 \mathrm{VA})_{2}\right\}\left(\mathrm{H}_{2} \mathrm{O}\right)_{4}\right]$ is $12.10 \mathrm{mM}^{-1} \mathrm{~s}^{-1}$ which corresponds to 6.50 "per Gd". The "per Gd" $r_{2 p}$ value of the complex is higher than that of the parent mononuclear complex $\left[\mathrm{Gd}(\mathrm{DO} V \mathrm{VA})\left(\mathrm{H}_{2} \mathrm{O}\right)_{2}\right]$. The higher transverse relaxivity is due to the presence of the 2-isovaleric acid groups on the periphery. The ratio $r_{2 p} / r_{1 p}$ is 1.06 which shows that the complex is a $T_{1}$-weighted contrast agent. The outer-sphere contribution to the overall relaxivity is attributed to the presence of a large number of water molecules hydrogen bonded on the periphery of the ligand framework. The importance of the spacer in accelerating relaxivity is also reflected in the $r_{2 p}$ value.

Relaxivity of the complexes in the presence of $H S A$.
The complexes $\left[\mathrm{Gd}_{2}\left\{\mathrm{pr}(\mathrm{DO} 3 \mathrm{VA})_{2}\right\}\left(\mathrm{H}_{2} \mathrm{O}\right)_{4}\right]$ [Gd(DOTVA) $\left(\mathrm{H}_{2} \mathrm{O}\right)$ ] exhibit $r_{1 p}$ value of 30.51 and $r_{2 p}$ value of $36.25 \mathrm{mM}^{-1} \mathrm{~s}^{-1}$ in the presence of HSA $(1.36 \%)$ which is 2.69 times higher than that of the complex in neat aqueous solution. The higher relaxivity of the complexes is due to the binding of the 2-isovaleric acid pendant arm with the serum protein which results in a higher rotational correlation time for the macromolecular adduct. This promises their use as blood pool CAs for magnetic resonance angiography.

pH Dependent Relaxivity of complex. The dinuclear complex $\left[\mathrm{Gd}_{2}\left\{\operatorname{pr}(\mathrm{DO} 3 \mathrm{VA})_{2}\right\}\left(\mathrm{H}_{2} \mathrm{O}\right)_{4}\right]$ exhibits longitudinal relaxivities $\left(r_{1 p}\right)$ of $29.9,26.3,22.6$, and $18.3 \mathrm{mM}^{-1} \mathrm{~s}^{-1}$ at $\mathrm{pH}$ 2.6, 3.6, 4.6, and 5.6, respectively. These values are significantly higher than that of the complex in neat solution $\left(r_{1 \mathrm{p}}=11.32 \mathrm{mM}^{-1} \mathrm{~s}^{-1}, \mathrm{pH}=7\right)$. The relaxivity values at $\mathrm{pH}$ 7.2, 7.5, and 8.0 (TRIS-HCl buffer) are 9.45, 8.21, and 4.96, respectively. However, at $\mathrm{pH} 8.5,9.6$, and 10.6 the complex shows the longitudinal relaxivity of $0.39,0.38$, and 0.41 , respectively (Figure-2).

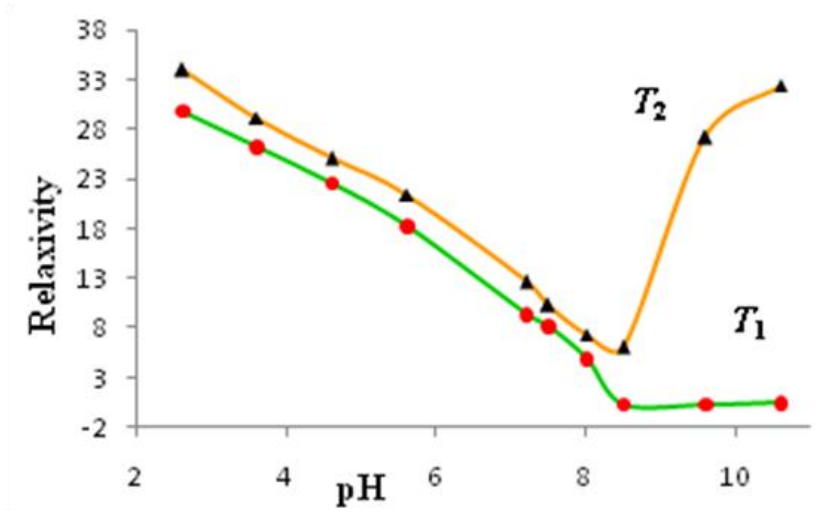

Fig.3. pH vs relaxivity $\left(T_{1 p}\right.$ and $\left.T_{2 p}\right)$ values of the complex

The higher relaxivity at low $\mathrm{pH}$ may be caused by the protonation of the carboxylate oxygen, the nitrogen atoms of the ligand, and the water molecules hydrogen bonded to the periphery of the DO3VA chelates. The distinct change in the relaxivity values shows that the complex undergoes protonation at low $\mathrm{pH}$. These $\mathrm{pH}$ responsive complexes could be good contrast agents in imaging the affected tissue in cancer diagnosis.

\section{CONCLUSIONS}

In the present investigation a convenient methodology has been developed for the synthesis of dinuclear linker, ligand and their gadolinium(III) complexes of 1,4,7,10tetraazacyclododecane-1,4,7,-tri-2-isovaleric acid DO3VA] as contrast enhancing agents for MRA application. The higher relaxivity of the dinuclear complexes indicates that each of the DO3VA moieties covalently appended to the linker or core molecule coordinates to the $\mathrm{Gd}(\mathrm{III})$ ion 
independently with inner-sphere water molecule(s). The outer-sphere contribution to the overall relaxivity is attributed to the presence of a large number of water molecules hydrogen bonded to the periphery of the hydrophilic 2-isovaleric acid groups. It is interesting to note that in the dinuclear [Gd(DO3VA)] chelates the "per Gd" relaxivity increases with the nuclearity of the complex. In the case of dinuclear $\mathrm{Gd}(\mathrm{III})$ chelates an additional contribution to the overall relaxivity may arise from the paramagnetic interactions between the gadolinium(III) ions. The 2-isovaleric acid pendant arm appears to be a versatile moiety in the development of new contrast agents for MRI. These complexes with the potential of binding with HSA through non-covalent interactions may offer a wide scope of evaluating their suitability as blood pool agents for magnetic resonance angiography (MRA). Also we reported the $\mathrm{pH}$ modulated relaxivity of the complex between 2.6 to $10.6 \mathrm{pH}$. The change in relaxivity with corresponds to the change in $\mathrm{pH}$ shows the suitability of the complex as $\mathrm{pH}$ probes for determining the tumors.

\section{ACKNOWLEDGMENT}

This research was carried out with the financial support from the Department of Science and Technology (DST), Government of India. We thank Dr. M. S. Moni, SAIC, IIT-M, Chennai, for recording the NMR spectra and the RSIC, CDRI, Lucknow, for recording ESI mass spectra. We wish to record our sincere gratitude to Mr.I.George David of chemistry department for his strong support and help.

\section{REFERENCES AND NOTES}

[1]. (a) Caravan, P.; Ellison, J. J.; McMurry, T. J.; Lauffer, R. B. Chem. Rev. 1999, 99, 2293-2352. (b) The Chemistry of Contrast Agents in Medical Magnetic Resonance Imaging; Merbach, A. E., Toth, E., Eds.; John Wiley \& Sons, Ltd.: New York, 2001. (c) Bottrill, M.; Kwok, L.; Long, J. N. Chem. Soc. Rev. 2006, 35, 557-571.

[2]. Jendrasiak, L. G.; Smith, L. R.; Ribeiro, A. A. Phys. Med. Biol. 2000, 45, 3109-3122.

[3]. Louie, A. Y.; Huber, M. M.; Ahrens, E. T.; Rothbacher, U.; Moats, R.; Jacobs, R. E.; Fraser, S. E.; Meade, T. J. Nat. Biotechnol. 2000, 18, 321-325.

[4]. (a) Richardson, J. C.; Bowtell, R. W.; Mader, K.; Melia, C. D. Adv. Drug. Dev. Rev. 2005, 57, 1191-1209. (b) Ye, F.; Ke, T.; Jeong, E.-K.; Wang, X.; Sun, Y.; Johnson, M.; Lu, Z.-R. Mol. Pharm. 2006, 3, 507-515.

[5]. Caravan, P. Chem. Soc. Rev. 2006, 35, 512-523.

[6]. (a) Bianchi, A.; Calabi, L.; Corana, F.; Fontana, S.; Losi, P.; Maiocchi, A.; Paleari, L.; Valtancoli, B. Coord. Chem. Rev.
2000, 204, 309-393. (b) Brucher, E. Top. Curr. Chem. 2002, 221, 103-122.

[7]. (a) Lauffer, R. E.; Chem. Rev. 1987, 87, 901-927. (b) Aime, S.; Botta, M.; Terreno, E. Adv. Inorg. Chem. 2005, 57, 173237. (c) Kubicek, V.; Toth. E. Adv. Inorg. Chem. 2009, 61, 63-129. (d) Gilsoul, D.; Hermann, M.; Humblet, V.; Jacques, V.; Mesbahi, M.; Sauvage, C.; Desreux, J. F. Coord. Chem. Rev. 1999, 185-186, 451-470. (e) Frullano, L.; Rohovec, J.; Peters, J. A.; Geraldes, C. F. G. C. Top. Curr. Chem. 2002, 221, 25-60. (f) Toth, E.; Helm, L.; Merbach, A. E. Top. Curr. Chem. 2002, 221, 61-101. (g) Aime, S.; Botta, M.; Fasano, M.; Crich, G. S.; Terreno, E. Coord. Chem. Rev. 1999, 185-186, 321-333. (h) Chan, K. W.-Y.; Wong, W.-T. Coord. Chem. Rev. 2007, 251, 24282451. (i) Gries, H. Top. Curr. Chem. 2002, 221, 1-24. (j) Terreno, E.; Castelli, D. D.; Viale, A.; Aime, S. Chem. Rev. 2010, 110, 3019-3042.

[8]. Weinmann, H. J.; Brasch, R. C.; Press, W. R.; Wesby, G. E. Am. J. Roentgenol. 1984, 142, 619-624.

[9]. (a) Penfield, J. G.; Reilly, R. F. Nat. Clin. Pract. Nephrol. 2007, 3, 654-668. (b) Gu, S.; Kim, H.-K.; Lee, H. G.; Kang, B.-S.; Chang, Y.; Kim, T.-J. J. Med. Chem. 2011, 54, 143152. (c) Villaraza, A. J. L.; Bumb, A.; Brechbiel, M. W. Chem. Rev. 2010, 110, 2921-2959.

[10]. (a) Powell, D. H.; Dhubhghaill, O. M. N.; Pubanz, D.; Helm, L.; Lebedev, Y. S.; Schlaepfer, W.; Merbach, A. E. J. Am. Chem. Soc. 1996, 118, 9333-9346. (b) Toth, E.; Helm, L.; Merbach, A. E. In The Chemistry of Contrast Agents in Medical Magnetic Resonance Imaging; Merbach, A. E., Toth, E., Eds.; Wiley-VCH: Weinheim, Germany, 2001; Chapter 2, pp 45-119.

[11]. (a) Caravan, P. Acc. Chem. Res. 2009, 42, 851-862. (b) Rebizak, R.; Schaefer, M.; Dellacherie, E. Bioconjugate Chem. 1998, 9, 94-99. (c) Siauve, N.; Clement, O.; Cuenod, C. A.; Benderbous, S.; Frija, G. Magn. Reson. Imaging 1996, 14, 381-390. (d) Kellar, K. E.; Henrichs, P. M.; Hollister, R.; Koenig, S. H.; Eck, J.; Wei, D. Magn. Reson. Med. 1997, 38, 712-716. (e) Zhou, Z.; Guo, J.; Yu, H.; Zhu, B.; Liu, C.; Jiang, X.; Zhang, M.; Chen, J. J. Magn. Reson. Imaging 2005, 22, 361-367. (f) Plush, E. S.; Woods, M.; Zhou, F.-Y.; Kadali, B. S.; Wong, S, M.; Sherry, A. D. J. Am. Chem. Soc. 2009, 131, 15918-15923. (g) Glogard, C.; Stensrud, G.; Aime, S. Magn. Reson. Chem. 2003, 41, 585588. (h) Nasongkla, N.; Bey, E.; Ren, J.; Ai, H.; Khemtong, C.; Guthi, J. S.; Chin, S.-F.; Sherry, A. D.; Boothman, D. A.; Gao, J. Nano Lett. 2006, 6, 2427-2430. (i) Margerum, L. D.; Campion, B. K.; Koo, M.; Shargill, N.; Lai, J. J.; Marumoto, A.; Sontum, P. C. J. Alloys Compds. 1997, 249, 185-190. (j) Toth, E.; Pubanz, D.; Vauthey, S.; Helm, L.; Merbach, A. E. Chem. Eur. J. 1996, 2, 1607-1615. (k) Nicolle, G. M.; Toth, E.; Schmitt-Willich, H.; Raduchel, B. E.; Merbach, A. E. Chem. Eur. J. 2002, 8, 1040-1048. (I) Rudovsky, J.; Hermann, P.; Botta, M.; Aime, S.; Lukes, I. Chem. Commun. 2005, 2390-2392.

[12]. Hernandez, G.; Brittain, H. G.; Tweedle, M. F.; Bryant, R. G. Inorg. Chem. 1990, 29, 985-988. 
[13]. (a) Jebasingh. B.; Alexander. V. Inorg. Chem. 2005, 44, 9434-9443. (b) Toth, E.; Vauthey, S.; Pubanz, D.; Merbach, A. E. Inorg. Chem. 1996, 35, 3375-3379. (c) Bovens, E. Z.; Elst, L. V.; Muller, R. N.; Bekkum, H. V.; Peters, J. A. Eur. J. Inorg. Chem. 2001, 3101-3105. (d) Lee, T. M.; Cheng, T. H.; Ou, M. H.; Chang, C. A.; Liu, G. C.; Wang, Y. M. Magn. Reson. Chem. 2004, 42, 329-336. (e) Li, W. H.; Fraser, S. E.; Meade, T. J. J. Am. Chem. Soc. 1999, 121, 1413-1414. (f) Li, W. H.; Parigi, G.; Fragai, M.; Luchinat, C.; Meade, T. J. Inorg. Chem. 2002, 41, 4018-4024. (g) Ruloff, R.; VanKoten, G.; Merbach, A. E. Chem. Commun. 2004, 842843. (h) Livramento, J. B.; Toth, E.; Sour, A.; Borel, A.; Merbach, A. E.; Ruloff, R. Angew. Chem., Int. Ed. 2005, 44, 1480-1484. (i) Costa, J.; Toth, E.; Helm, L.; Merbach, A. E. Inorg. Chem. 2005, 44, 4747-4755.

[14]. (a) Roglin, L.; Lempens, E. H. M.; Meijer, E. W. Angew. Chem., Int. Ed. 2011, 50, 102-112. (b) Mintzer, M. A.; Grinstaff, M. W. Chem. Soc. Rev. 2011, 40, 173-190. (c) Wiener, E.; Narayanan, V. In Advances in Dendritic Macromolecules; Newkome, G. R., Ed.; Elsevier Science Ltd.: New York, 2002; pp 129-247. (d) Dong, Q.; Hurst, D. R.; Weinmann, H. J.; Chenevert, T. L.; Londy, F. J.; Prince, M. R. Invest. Radiol. 1998, 33, 699-708. (e) Tacke, J.; Adam, G.; Claben, H.; Muhler, A.; Prescher, A.; Gunther, R. W. Magn. Reson. Imaging 1997, 7, 678-682. (f) Roberts, H. C.; Saeed, M.; Roberts, T. P. L.; Muhler, A.; Shames, D. M.; Mann, J. S.; Stiskal, M.; Demsar, F.; Brasch, R. C. Magn. Reson. Imaging 1997, 7, 331-338. (g) Roberts, H. C.; Saeed, M.; Roberts, T. P. L.; Brasch, R. C. Acad. Radiol. 1998, 5, S31-S33. (h) Xu, R.; Wang, Y.; Wang, X.; Jeong, K.-E.; Dennis, L.; Lu, R.-Z, Exp. Biol. Med. 2007, 232, 1081-1089. (i) Bryson, M. J.; Chu, W.-J.; Lee, J.-H.; Reinekebio, M. T. Bioconjugate Chem. 2008, 19, 1505-1509. (j) Wiener, E. C.; Brechbiel, M. W.; Brothers, H.; Magin, R. L.; Gansow, A.; Tomalia, D. A.; Lauterber, P. C. Magn. Reson. Med. 1994, 31, 1-8. (k) Langereis, S.; de Lussanet, G. Q.; Van Genderen, P. H. M.; Backes, H. W.; Meijer, E. W. Macromolecules 2004, 37, 3084-3091. (m) Floyd, W. C.; Klemm, P. J.; Smiles, D. E.; Kohlgruber, A. C.; Pierre, V. C.; Mynar, J. L.; Jean M. J. Frechet, J. M. J.; Raymond, K. N. J. Am. Chem. Soc. 2011, 133, 2390-2393.

[15]. Furniss, B. S.; Hannaford, A. J.; Rogers, V.; Smith, P. W. G.; Tatchell, A. R.; Vogel's Textbook of Practical Organic Chemistry; 4th ed: English Language Book Society; 1976; pp 457-458.
[16]. Dawson, R. M. C.; Elliott, D. C.; Elliott, W. H.; Jones, K. M. Data for Biochemical Research; Oxford University Press: Oxford; 1969; pp 475-508.

[17]. Pearse, A. G. E. In Histochemistry, Theoretical and Applied; Pearse, A. G. E., Ed.;Churchill Livingstone: Edinburgh, 1980; Vol. 1, p 167.

[18]. (a) Gomori, G. Methods in Enzymology; Kaplan, N. O., Colowick, S. P., Ed.; Academic Press Inc.: New York; 1955; Vol. 1, p 138. (b) Sorensen, S. P. L. Biochem. Z. 1909, 22, 352-375.

[19]. Vold, R. V.; Waugh, J. S.; Klein, M. P.; Phelps, D. E. J. Chem. Phys. 1968, 48, 3831-3832.

[20]. Shukla, R. B.; Kumar, K.; Weber, R.; Zhang, X.; Tweedle, M. F. Acta Radiologica 1997, 38, 121-123.

[21]. Meiboom, S.; Gill, D. Rev. Sci. Instrum. 1958, 29, 688-691.

[22]. Herzog, H. L. Org. Syn. 1972, 753-755.

[23]. (a) Nakamoto, K. Infrared and Raman Spectra of Inorganic and Coordination Compounds; $4^{\text {th }}$ ed; John-Wiley \& Sons, Inc.: New York, 1986. (b) Andre, J. P.; Maecke, H. R.; Toth, E.; Merbach, A. E. J. Biol. Inorg. Chem. 1999, 4, 341-347. (c) Silverstein, R. M.; Bassler, G. C.; Morrill, T. C. Spectrometric Identification of Organic Compounds; $5^{\text {th }}$ ed: John Wiley \& Sons, Inc.: New York, 1991.

[24]. Kubieck, K.; Rudovsky, J.; Kotek, J.; Hermann, P.; Vander, L. E.; Muller, R. N.; Zvonimir, I. K.; Wolterbeek, H.; Peter, J. A.; Lukes, I. J. Am. Chem. Soc. 2005, 127, 16477-16485.

[25]. Undheim, K.; Gronneberg, T. Acta Chem. Scand. 1971, 25, 18-26.

[26]. Brunisholz, G.; Randin, M. Helv. Chim. Acta. 1959, 42, 1927-1938.

[27]. (a) Paris, J.; Gameiro, C.; Humblet, V.; Mohapatra, K. P.; Jacques, V.; Desreux, F. J. Inorg. Chem. 2006, 45, 50925102. (b) Ranganathan, R. S.; Fernandez, M. E.; Kang, S. I.; Nunn, A. D.; Rastep, P. C.; Pillai, K. M. R.; Zhang, X.; Tweedle, M. F. Invest. Radiol. 1998, 33, 779-797. (c) Henig, J.; Toth, E.; Engelmann, J.; Gottschalk, S.; Mayer, A. H. Inorg. Chem. 2010, 49, 6124-6138. 